Zeszyty Naukowe Szkoły Głównej Gospodarstwa Wiejskiego w Warszawie

Problemy Rolnictwa Światowego tom 18 (XXXIII), zeszyt 4, 2018: 209-221

DOI: 10.22630/PRS.2018.18.4.112

Karolina Jąder $^{1}$

Uniwersytet Przyrodniczy w Poznaniu

\title{
Produkcja, konsumpcja i eksport jabłek w Polsce w latach 2005-2016
}

\section{Production, Consumption and Export in Poland in the years 2005-2016}

\begin{abstract}
Synopsis. Celem artykułu było przedstawienie zmian na rynku jabłek w Polsce w latach 2005-2016. W analizowanym okresie nastapiło wyraźne zwiększenie znaczenia jabłek w polskiej produkcji sadowniczej. Odnotowano dynamiczny wzrost zbiorów, przy ograniczonym wzroście powierzchni. W tym czasie odnotowano również zmiany w strukturze odmianowej jabłek. Umacniał się udział odmiany Idared oraz wzrastało znaczenie odmian Gala i Ligol. Tendencją spadkową charakteryzowała się natomiast konsumpcja jabłek, a ich znaczenie w strukturze spożycia owoców malało na korzyść owoców południowych. W badanym okresie wzrastała wielkość i wartość sprzedaży zagranicznej jabłek, a także zaszły duże zmiany w strukturze geograficznej eksportu.
\end{abstract}

Slowa kluczowe: jabłka, powierzchnia, zbiory, konsumpcja, eksport

\begin{abstract}
The aim of the article was to present changes on the apples market in Poland in 2005-2016. Results show that in the analyzed period the importance of apples in Polish fruit production increased. There has been a increase in crops with limited area growth. During this time, changes in the structure of apples varieties were also noted. The importance of the Idared, Gala and Ligol varieties grew. Consumption of apples was characterized by decreasing tendency. The importance of apples in the fruit consumption structure decreased and the share of exotic fruit increased. In the analyzed period, the volume and value of foreign sales of apples increased, as well a significant change in the geographical structure of exports were observed.
\end{abstract}

Key words: apples, area, crops, consumption, export

JEL Classification: Q13, Q17, Q18

\section{Wprowadzenie}

Od początku rozwoju polskiego sadownictwa uprawa jabłoni i produkcja jabłek miała bardzo duże znaczenie w produkcji ogrodniczej i rolniczej. Dzięki postępowi w sadownictwie, a przede wszystkim zmianie technologii produkcji z niskopiennych sadów jabłoniowych na karłowe, roczne zbiory jabłek na przestrzeni ostatnich kilkudziesięciu lat wzrosły do ok. 4 mln ton. W chwili obecnej nasz kraj, po Chinach i USA jest trzecim, największym producentem tego gatunku owoców na świecie, natomiast wśród krajów europejskich zajmujemy zdecydowanie pierwsze miejsce (Bugała, 2014). Wielkość produkcji w rekordowym, 2016 roku wyniosła ponad $4 \mathrm{mln}$ ton, co pozwoliło nam zdecydowanie wyprzedzić takie kraje jak Włochy, Francja czy Niemcy, gdzie zbiory

${ }^{1}$ dr inż., Katedra Prawa i Organizacji Przedsiębiorstw w Agrobiznesie UP w Poznaniu, ul. Wojska Polskiego 28, 60-637 Poznań, e-mail: karolina.jader@up.poznan.pl; https://orcid.org/0000-0002-4047-7386 
osiągnęly poziom, wynoszący odpowiednio ok. $2 \mathrm{mln}$ ton, $1,5 \mathrm{mln}$ ton i $1 \mathrm{mln}$ ton (WAPA, 2017). O dużym znaczeniu produkcji jabłek w Polsce świadczy przede wszystkim ich bardzo wysoki udział w krajowej produkcji owoców, który w latach 2005-2016 wyniósł średnio ponad $70 \%$. W tym samym czasie, w UE stanowiły one ok. $30 \%$ wszystkich zbieranych owoców. Wysoki poziom produkcji sprawia, że nasz kraj znajduje się też w pierwszej dziesiątce największych światowych eksporterów jabłek. Wśród krajów europejskich wyprzedzają nas tutaj tylko Włochy i Francja. Średnio co roku w latach 20052016 za granice sprzedawano ok. 30\% zebranych jabłek. Znaczna część, bo ok. 40\% produkcji kierowana jest do przetwórstwa, w tym głównie na produkcję zagęszczonego soku jabłkowego, przeznaczanego w ok. 90\% na eksport (Kierczyńska, 2015).

Na konkurencyjność polskich jabłek oraz ich przetworów na światowym i europejskim rynku wpływa przede wszystkim wysoka produkcja i od kilkunastu lat widoczna wyraźnie coraz lepsza jakość owoców, która umożliwia zdobywanie nowych rynków zbytu. Zmiany zachodzące na rynku jabłek są wynikiem oddziaływania szeregu czynników, spośród których największe znaczenie maja czynniki przyrodnicze, ekonomiczne i polityczne.

Celem niniejszego opracowania było przedstawienie i ocena zmian na rynku jabłek w Polsce w latach 2005-2016.

\section{Materiał i metodyka badań}

Analizę oparto na danych wtórnych, pochodzących z publikacji Głównego Urzędu Statystycznego „Wyniki produkcji roślinnej w latach 2005-2016” oraz Instytutu Ekonomiki Rolnictwa i Gospodarki Żywnościowej "Rynek owoców i warzyw" z lat 2006-2017. W opracowaniu przedstawiono zmiany, jakie zaszły w latach 2005-2016 w produkcji, konsumpcji i eksporcie jabłek. Szczegółowo zbadano powierzchnię upraw i zbiory jabłek, z uwzględnieniem struktury odmianowej, a także określono znaczenie produkcji jabłek w całej produkcji sadowniczej. Przedstawiono zmiany w wielkości, wartości i strukturze geograficznej eksportu jabłek oraz zdefiniowano udział sprzedaży zagranicznej jabłek w eksporcie wszystkich owoców. Dla określenia tendencji na rynku jabłek posłużono się metoda regresji liniowej, natomiast $\mathrm{w}$ celu zdefiniowania procentowych zmian w porównywanych okresach zastosowano wskaźniki dynamiki.

\section{Powierzchnia upraw jabłoni i zbiory jabłek}

W latach 2005-2016 jabłka w Polsce uprawiano średnio co roku na powierzchni 406,4 tys. ha. Podobnie jak w areale upraw wszystkich owoców nie nastąpiły tutaj wyraźne zmiany i stwierdzono tylko niewielką tendencję wzrostową. Co roku ich uprawy zwiększały się przeciętnie o 0,5 tys. ha (rys.1). Porównując skrajne analizowane lata stwierdzono wzrost o 7,5 tys. ha, tj. 4,4\%. Najmniejszy areał jabłoni, 162 tys. ha odnotowano w 2006 roku, natomiast najwyższy, wynoszący 194,7 tys. ha w 2012 roku. Powierzchnia sadów jabłoniowych stanowiła $\mathrm{w}$ tym okresie średnio $43,7 \%$ wszystkich upraw owoców oraz $65,2 \%$ areału drzew owocowych. Porównując lata 2005 i 2016, udział jabłoni w strukturze powierzchni upraw wszystkich owoców zwiększył się o 1,8 pkt. proc., a w grupie owoców z drzew znaczenie omawianego gatunku wzrosło jeszcze wyraźniej, bo o 5,2 pkt. proc. Było to bezpośrednio wynikiem zmian jakie zaszły w analizowanym 
okresie w powierzchni tych trzech grup. Porównując skrajne analizowane lata, stwierdzono wzrost areału upraw jabłoni o 4,4\%, ogólna powierzchnia upraw owoców wzrosła zaledwie o $0,3 \%$, natomiast ilość hektarów przeznaczanych pod sady zmniejszyła się o 3,1\%.

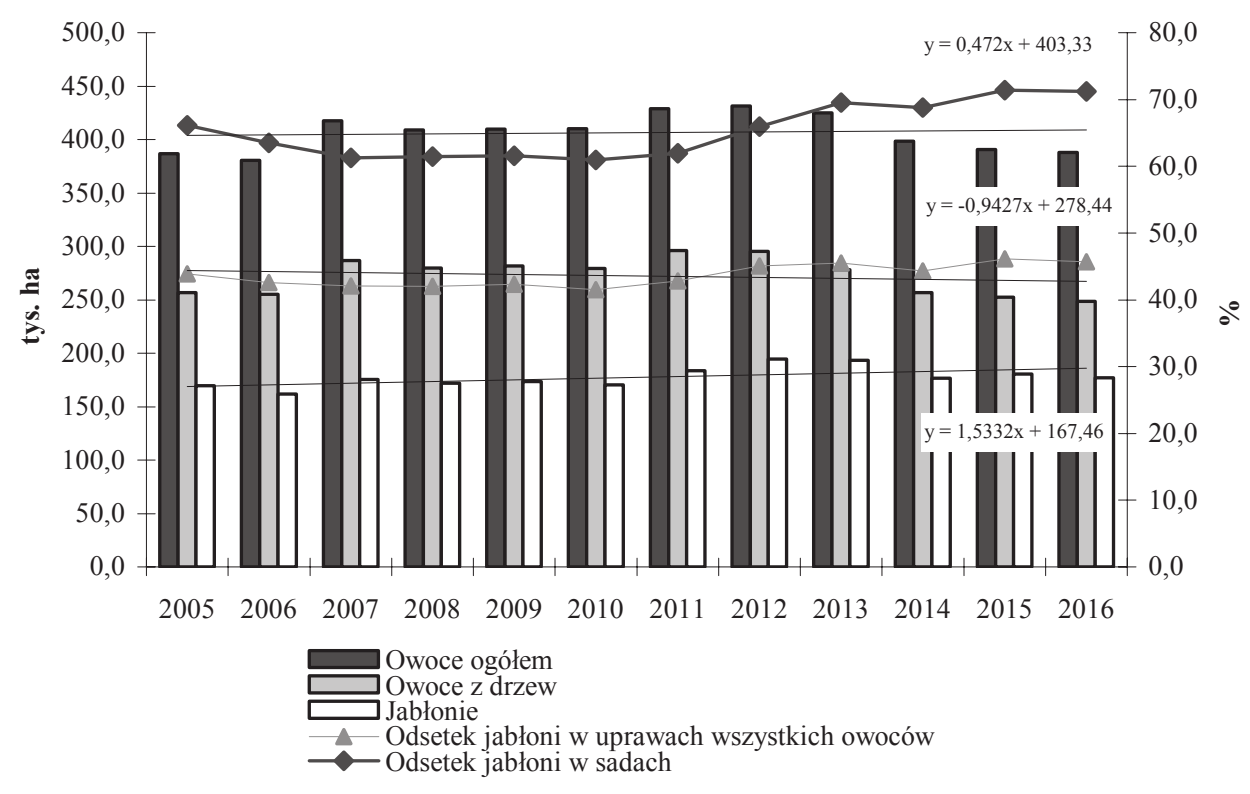

Rys. 1. Powierzchnia owoców ogółem, sadów i jabłoni w Polsce w latach 2005-2016

Fig. 1. Total area of fruit, orchards and apple trees in Poland in 2005-2016

Źródło: obliczenia własne na podstawie (Rynek owoców..., 2006-2017)

Dominacja jabłek w polskim sadownictwie jeszcze wyraźniej widoczna była patrząc na wyniki analizy uzyskiwanych efektów produkcyjnych. Średnie zbiory jabłek wyniosły w badanym okresie 2597,2 tys. ton, a ich wielkość średnio z roku na rok wzrastała o 147,2 tys. ton (rys. 2). Porównując pierwszy i ostatni rok analizy, stwierdzono zwiększenie produkcji o $73,7 \%$, z poziomu 2075 do 3604,2 tys. ton.

Omawiając zbiory owoców należy wspomnieć o dużej ich zmienności, uzależnionej głównie od warunków atmosferycznych. Najwięcej, 3604,2 tys. ton jabłek zebrano w 2016 roku, a wyraźnie najmniej w latach 2007 i 2010, gdy produkcja osiagnęła poziom wynoszący odpowiednio 1040 i 1888,9 tys. ton. Tak niskie zbiory były wynikiem bardzo niekorzystnych warunków atmosferycznych w tych latach. W 2007 roku bezpośrednią przyczyną były przymrozki w okresie kwitnienia, natomiast w 2010 roku nadmierne opady i ekstremalne temperatury (Wyniki produkcji roślinnej... 2008, 2011). Dysproporcja między latami 2016 i 2007, tj. latami z największą i najmniejszą produkcją wyniosła ponad 2,5 mln ton. Największa różnica w zbiorach w dwóch następujących po sobie okresach, dotyczyła lat 2007 i 2008 i osiagnęła poziom blisko 1,8 mln ton.

W latach 2005-2016 nastapił wyraźny wzrost zbiorów wszystkich owoców oraz tych uprawianych w sadach i wyniósł on odpowiednio 58,7\% i 67,9\%. Wyraźne zwiększenie produkcji, przy minimalnym wzroście lub nawet spadku powierzchni uprawnej owoców 
było następstwem wyraźnych zmian, jakie zaszły w polskim sadownictwie na przestrzeni ostatnich kilkunastu lat. Szczególną uwagę należy zwrócić tutaj na zmiany w technologii produkcji, modernizacje gospodarstw $\mathrm{i}$ wynikający $\mathrm{z}$ nich wzrost plonów. Należy zauważyć, że podobnie jak w przypadku powierzchni, zmiany w produkcji jabłek były większe niż w zbiorach wszystkich owoców czy owoców z drzew. Wpłynęło to na zwiększenie znaczenia jabłek w strukturze zbiorów owoców. W badanym okresie stanowiły one średnio $72,7 \%$ wszystkich zbieranych owoców oraz $86,7 \%$ owoców z drzew. Ich udział w jednej i drugiej grupie zwiększył o odpowiednio 6,6 i 3,0 pkt. proc.

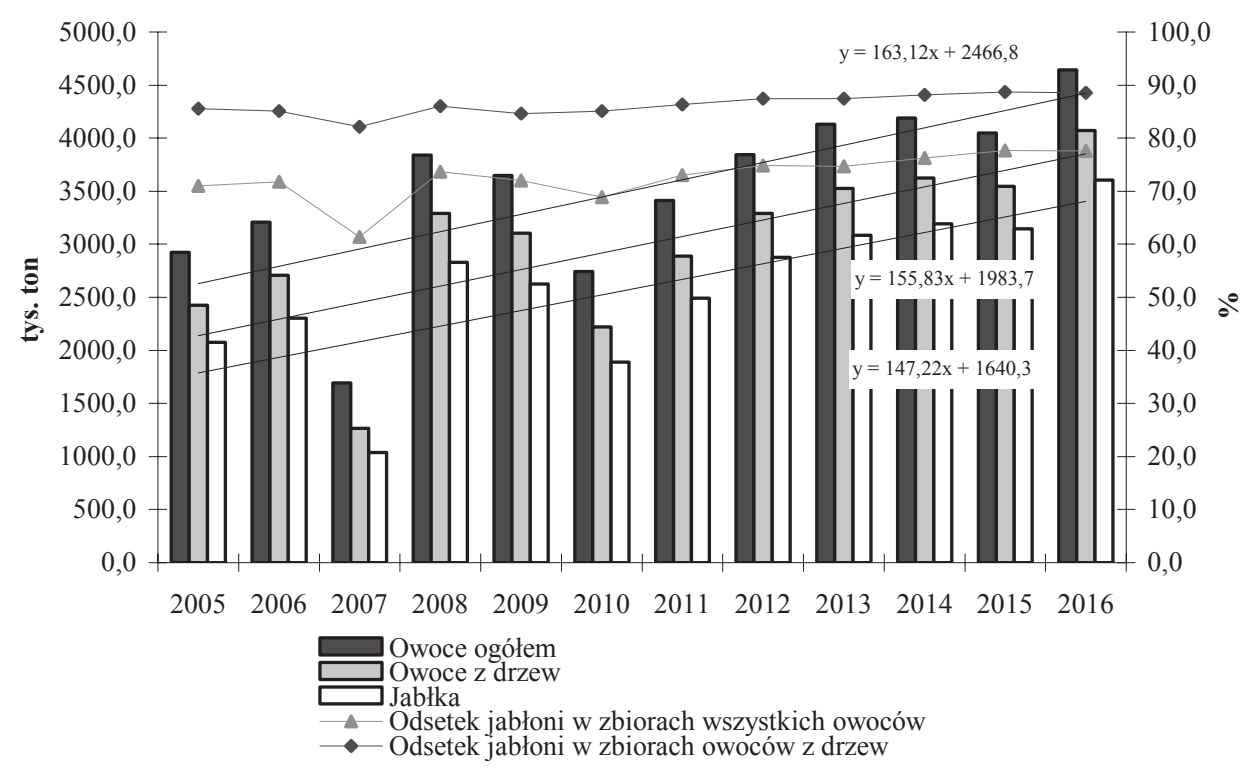

Rys. 2. Zbiory owoców ogółem, owoców z drzew i jabłek w Polsce w latach 2005-2016

Fig. 2. Total fruit crops, fruit from trees and apples in Poland in 2005-2016

Źródło: obliczenia własne na podstawie (Rynek owoców ... 2006-2017)

Charakterystyczną cechą polskiej produkcji jabłek jest bardzo duża różnorodność uprawianych odmian, przy czym trzy z nich, tj. Idared, Jonagold i Szampion stanowią blisko $40 \%$ nasadzeń oraz zbiorów (tab. 1). $\mathrm{Z}$ trzech w/w odmian największą powierzchnię zajmował Idared. W latach 2013-2016 roczny areał jej nasadzeń wyniósł średnio 33,8 tys. ha, natomiast średnie roczne zbiory osiagały poziom 619,1 tys. ton. Stanowiło to $18,5 \%$ powierzchni jabłoni i $19 \%$ wielkości produkcji jabłek. Udział w powierzchni i zbiorach jabłek Jonagold i Szampion wynosił odpowiednio 9,7\% i 10,6\% oraz 9,8\% i 11,3\%. Znaczenie pozostałych odmian jabłoni było zdecydowanie mniejsze, gdyż odsetek powierzchni i zbiorów żadnej z nich nie przekraczał 10\%, a w przypadku większości nawet $5 \%$.

Wydzielenie trzech podokresów w latach 2005-2016 umożliwiło zdefiniowanie najważniejszych zmian jakie zaszły $\mathrm{w}$ strukturze odmianowej jabłek $\mathrm{w}$ analizowanym okresie. 
Tabela. 1. Powierzchnia jabłoni i zbiory jabłek w Polsce wg odmian

Table 1. Apple area and apple crops in Poland by variety

\begin{tabular}{|c|c|c|c|c|c|c|c|}
\hline \multirow[t]{3}{*}{ Wyszczególnienie } & \multicolumn{2}{|c|}{$2005-2008$} & \multicolumn{2}{|c|}{$2009-2012$} & \multicolumn{2}{|c|}{$2013-2016$} & $\begin{array}{c}\text { Dynamika zmian } \\
2013-2016 \\
/ 2005-2008 \\
2005-2008=100\end{array}$ \\
\hline & \multicolumn{7}{|c|}{ Powierzchnia } \\
\hline & [tys. ha] & {$[\%]$} & [tys. ha] & {$[\%]$} & [tys. ha] & {$[\%]$} & \\
\hline Idared & 27,1 & 15,9 & 30,2 & 16,6 & 33,8 & 18,5 & 124,7 \\
\hline Jonagold & 19,0 & 11,2 & 19,6 & 10,9 & 17,7 & 9,7 & 93,0 \\
\hline Szampion & 16,5 & 9,7 & 18,4 & 10,2 & 19,4 & 10,6 & 117,4 \\
\hline Lobo & 13,7 & 8,0 & 12,2 & 6,8 & 7,3 & 4,0 & 53,6 \\
\hline Cortland & 14,2 & 8,4 & 13,7 & 7,6 & 8,8 & 4,8 & 62,2 \\
\hline Gloster & 10,2 & 6,0 & 10,5 & 5,8 & 10,1 & 5,6 & 99,3 \\
\hline Golden Delicious & 7,6 & 4,5 & 7,8 & 4,3 & 7,5 & 4,1 & 99,0 \\
\hline Ligol & 7,0 & 4,1 & 9,4 & 5,1 & 14,0 & 7,7 & 200,4 \\
\hline Elstar & 5,0 & 2,9 & 5,0 & 2,8 & 5,6 & 3,1 & 111,6 \\
\hline Red Delicious & 4,4 & 2,6 & 4,3 & 2,4 & 3,5 & 1,9 & 79,1 \\
\hline Gala & 3,8 & 2,3 & 5,1 & 2,8 & 6,9 & 3,8 & 182,2 \\
\hline Antonówka & 3,2 & 1,9 & 3,9 & 2,1 & 4,3 & 2,4 & 134,6 \\
\hline \multirow[t]{3}{*}{ Pozostałe } & 38,2 & 22,6 & 40,8 & 22,5 & 42,9 & 23,6 & 112,3 \\
\hline & \multicolumn{7}{|c|}{ Zbiory } \\
\hline & [tys. ton] & {$[\%]$} & [tys. ton] & {$[\%]$} & [tys. ton] & {$[\%]$} & \\
\hline Idared & 299,5 & 14,2 & 383,7 & 15,3 & 619,1 & 19,0 & 206,7 \\
\hline Jonagold & 218,5 & 10,7 & 271,9 & 11,1 & 318,6 & 9,8 & 145,8 \\
\hline Szampion & 200,7 & 9,7 & 287,9 & 11,7 & 367,7 & 11,3 & 183,2 \\
\hline Lobo & 173,9 & 8,3 & 164,5 & 6,8 & 125,2 & 3,8 & 72,0 \\
\hline Cortland & 173,1 & 8,2 & 174,9 & 7,2 & 145,8 & 4,5 & 84,2 \\
\hline Gloster & 132,5 & 6,3 & 184,5 & 7,6 & 198,5 & 6,1 & 149,8 \\
\hline Golden Delicious & 95,5 & 4,7 & 120,9 & 4,9 & 142,5 & 4,4 & 149,2 \\
\hline Ligol & 97,4 & 4,8 & 145,8 & 5,8 & 274,9 & 8,4 & 282,3 \\
\hline Elstar & 56,4 & 2,8 & 68,8 & 2,8 & 100,2 & 3,1 & 177,6 \\
\hline Red Delicious & 54,7 & 2,7 & 53,7 & 2,2 & 54,6 & 1,7 & 100,0 \\
\hline Gala & 61,8 & 3,1 & 79,5 & 3,2 & 135,4 & 4,1 & 218,9 \\
\hline Antonówka & 38,2 & 1,8 & 42,8 & 1,7 & 66,3 & 2,0 & 173,4 \\
\hline Pozostałe & 460,6 & 22,6 & 489,8 & 19,7 & 709,1 & 21,8 & 154,0 \\
\hline
\end{tabular}

Źródło: obliczenia własne na podstawie (Wyniki produkcji roślinnej w latach 2005-2016).

Porównując lata 2005-2008 i 2012-2016 swoja pozycję lidera umocniła odmiana Idared, której nasadzenia wzrosły o blisko $25 \%$ a zbiory ponad dwukrotnie. Spowodowało to wzrost udziału tej odmiany o 2,6 pkt. proc. w powierzchni i 4,7 pkt. proc. w zbiorach. $\mathrm{Z}$ trzech najważniejszych odmian wzrosło nieco znaczenie Szampiona, natomiast zmniejszył się nieco odsetek w strukturze odmiany Jonagold. Biorąc pod uwagę wszystkie odmiany, w analizowanym okresie najbardziej wzrosła powierzchnia nasadzeń odmian Ligol oraz Gala, o odpowiednio 100,4\% i 82,2\%. Jeszcze bardziej, bo o 182,3\% i 118,9\% zwiększyły się ich zbiory. Zmniejszenie powierzchni odnotowano w przypadku większości odmian, z wyjątkiem kilku, zwłaszcza tych, o których wspomniano powyżej. Na tej liście znalazły się głównie odmiany Lobo i Cortland, które w latach 2005-2008 należały do 
pierwszej piątki uprawianych odmian, jednak $\mathrm{w}$ ostatnim analizowanym podokresie zdecydowanie straciły na znaczeniu, co było wynikiem zmniejszenia powierzchni ich nasadzeń o odpowiednio ok. 50\% i 40\%. Główną przyczyną tych zmian były ograniczone możliwości eksportu tych odmian, spowodowane ich nieprzydatnością do transportu oraz dużą wrażliwością na choroby. $Z$ tego względu znaczenie tych odmian ogranicza się w dużej mierze do sprzedaży na krajowym rynku detalicznym.

Najważniejszym czynnikiem decydującym o doborze odmian jest rynek i preferencje konsumentów (www.ogrodnictwo.expert.pl). Struktura odmianowa jabłek w Polsce jest również tym uwarunkowana. Dominacja odmiany Idared wynika przede wszystkim $\mathrm{z}$ dużego zainteresowania tą odmianą, głównie $\mathrm{w}$ krajach wschodniej i południowowschodniej Europy, gdzie kierowany jest głównie eksport z Polski (www.e-sadownictwo). Zdecydowaną zaletą tej odmiany jest wysoka plenność, łatwość w produkcji, duża tolerancja na długi transport i możliwość przechowywania w zwykłej chłodni, a przez krótki czas nawet w przechowalni. Ceny uzyskiwane za owoce tej odmiany sa jednak bardzo niskie, często kształtujące się na granicy opłacalności. Można też spodziewać się, że ze względu na wzrost produkcji jabłek w Rosji i na Ukrainie i coraz bardziej ograniczone możliwości jej eksportu zainteresowanie polskich sadowników tą odmianą zacznie się zmniejszać. Należy jeszcze raz podkreślić, że jest to typowa odmiana eksportowa, gdyż krajowi konsumenci nie lubia jej. Zdecydowanie bardziej preferują np. odmianę Szampion, która ze względu na słodki smak, swoich zwolenników znajduje również w krajach Europy wschodniej oraz kilku krajach Europy zachodniej. Podobnie jak odmiana Idared jest plenna i łatwa $\mathrm{w}$ produkcji, a ceny $\mathrm{z}$ jej sprzedaży są wyższe. Odmianą godną podkreślenia i mającą przyszłość w polskich sadach jest odmiana Gala, która już wcześniej została wymieniona jako jedna $\mathrm{z}$ dwóch najbardziej zyskujących na popularności w ostatnich kilkunastu latach. Wzrost nasadzeń wynika tu głównie ze względów ekonomicznych i faktu, iż owoce tej odmiany a zwłaszcza jej paskowane sporty można sprzedawać na całym świecie po atrakcyjnych cenach. Ceny uzyskiwane w eksporcie należą do najwyższych spośród wszystkich uprawianych odmian. Poza tym jabłka te mają dobry smak, piękny kolor i łatwo się przechowują. Polacy w celach konsumpcyjnych nabywają najchętniej jabłka duże, dobrze wybarwione, częściej odmiany czerwone niż zielone, niekoniecznie słodkie (Bobrowska, 2013). Stąd też wspomniany wcześniej wzrost popularności odmiany Ligol, a zwłaszcza jej czerwonych sportów. Odmiana ta charakteryzuje się kwaśnym smakiem, a jej owoce spełniają wyżej wymienione wymagania. Na obecną chwilę traci ona jednak swoja popularność na rynkach eksportowych, zatem ma znaczenie głównie w sprzedaży krajowej.

Omawiając strukturę odmianową jabłek w Polsce należy zaznaczyć, iż jest ona zupełnie odmienna od tej na świecie czy nawet w innych krajach Unii Europejskiej. Na światowych rynkach dominują odmiany jednokolorowe, takie jak Golden Delicious, Red Delicious oraz Gala, które stanowią około 50\% światowej (WAPA 2017). Ich odsetek w polskiej produkcji w ostatnich kilkunastu latach nie przekroczył 10\%. W krajach Unii Europejskiej, w 2016 roku największe zbiory odnotowano w przypadku odmian Golden Delicious, Gala oraz Idared, a wynosity one odpowiednio 2406 tys. ton, 1314 tys. ton oraz 965 tys. ton (WAPA 2017). Stanowily one ok. $20 \%, 11 \%$ i $8 \%$ europejskiej produkcji. Udział tych trzech odmian w polskich zbiorach wyniósł natomiast niecałe $20 \%$. W Polsce dominują ciagle jeszcze jabłka dwukolorowe i jak informował w roku 2017 prof. Makosz, chociaż odsetek wszystkich jednokolorowych odmian w polskiej produkcji wynosi $47 \%$, to udział odmian jednokolorowych, które znajdują zbyt i spełniają normy rynków 
zagranicznych osiagga poziom tylko 23\% (www.e-sadownictwo.pl). Wyraźnie podkreślał on również, że istnieje konieczność zmian w strukturze odmianowej jabłek w Polsce na korzyść odmian jednokolorowych, natomiast udział jabłek dwukolorowych nie powinien przekraczać 20-30\%. Do odmian, które polscy sadownicy powinni w szczególności uwzględnić w swoich nasadzeniach, należą wyżej wymienione odmiany, tj. Gala i jej paskowane sporty oraz Golden Delicious, a także nowe odmiany zyskujące coraz bardziej na popularności na rynkach zagranicznych, takie jak Jonaprince, Mutsu czy Pinova.

\section{Konsumpcja jabłek}

Z polskiej produkcji jabłek, około 50\%, ton kierowanych jest na rynek jabłek deserowych. Wykorzystywane są one do spożycia w stanie świeżym w kraju oraz przeznaczane są na eksport. Pozostała część trafia do przetwórstwa. Rosnąca na przestrzeni ostatnich kilkunastu lat produkcja jabłek i ich przetworów nie idzie w parze niestety ze wzrostem ich spożycia. Są one w naszym kraju traktowane przez wielu konsumentów jako dobra niższego rzędu wobec owoców południowych, których spożycie w ostatnich latach wzrasta i które zwiększają swoje znaczenie w strukturze konsumpcji owoców. Na przestrzeni analizowanych 12 lat spożycie owoców świeżych wynosiło średnio 40,7 $\mathrm{kg} / \mathrm{os} / \mathrm{rok}$ i co roku zmniejszało się o $0,06 \mathrm{~kg} / \mathrm{os}$. (rys.3). Najbardziej wyraźny spadek konsumpcji widoczny był do roku 2011, gdy zmniejszyła się ona z 43,2 do 37,7 kg/os/rok, natomiast $w$ dalszych latach nastąpił minimalny wzrost spożycia do poziomu $42 \mathrm{~kg} / \mathrm{os} / \mathrm{rok}$. Ilość konsumowanych owoców była zatem bardzo zbliżona do tej z pierwszych lat analizy, a porównując lata 2005 i 2016 stwierdzono spadek zaledwie o 3\%.

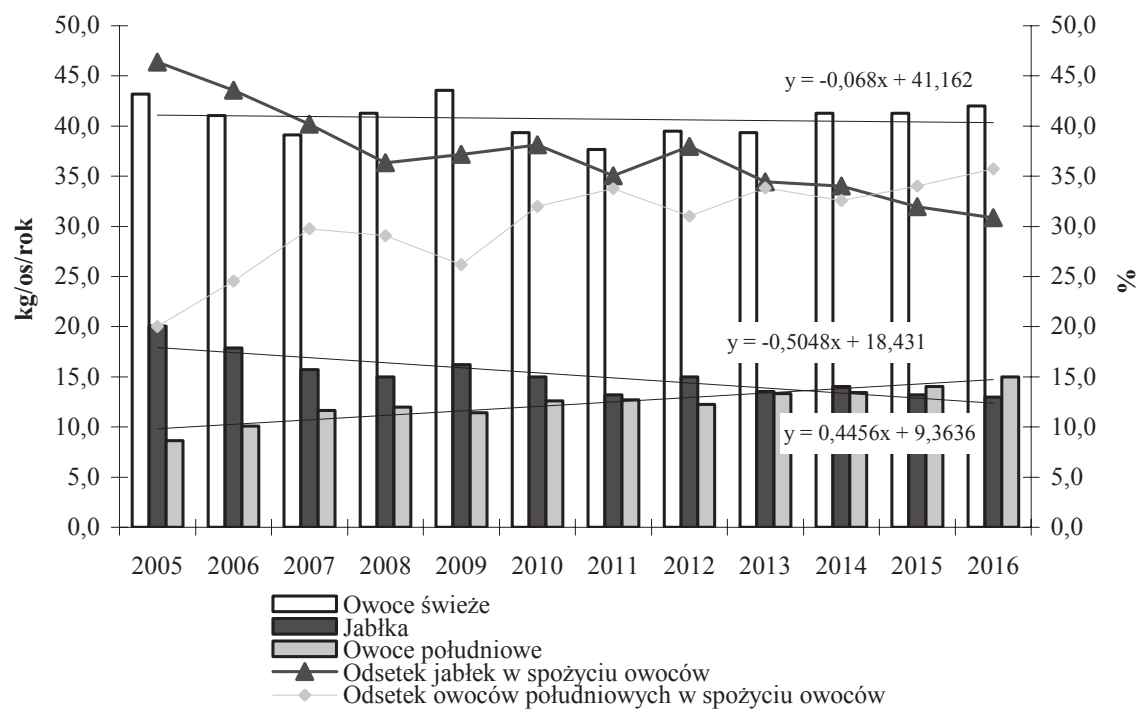

Rys. 3. Spożycie owoców ogółem, jabłek i owoców południowych w Polsce w latach 2005-2006

Fig. 3. Consumption of total fruits, apples and exotic fruits in Poland in 2005-2016

Źródło: obliczenia własne na podstawie (Rynek owoców ... 2006-2017). 
W latach 2005-2016 nastąpiły wyraźne zmiany w strukturze spożycia owoców. Najważniejsze z nich to wzrost udziału owoców południowych, w tym głównie bananów oraz spadek znaczenia jabłek. Średnie, roczne spożycie jabłek w badanym okresie wyniosło $15,2 \mathrm{~kg} / \mathrm{os}$, jednak na przestrzeni lat sukcesywnie malało, z poziomu $20 \mathrm{~kg} / \mathrm{os} / \mathrm{rok} \mathrm{w}$ roku 2005 do $13 \mathrm{~kg} / \mathrm{os} /$ rok w ostatnim roku analizy, co oznacza spadek o blisko 35\%. Największe zmniejszenie konsumpcji odnotowano w pierwszych czterech latach analizy, do roku 2008, jednak początek tendencji spadkowej dotyczy okresu już od roku 2002 (Jąder, 2014). Przyczyną tych zmian było zwiększenie spożycia owoców południowych, które z powodzeniem konkurowały ceną z naszymi krajowymi owocami. Ponadto wzrosła konsumpcja przetworów owocowych, głównie soków i nektarów i ogólnie zaczął zmieniać się model żywienia w kierunku wzrostu żywienia tzw. fast food. (Nosecka i in., 2012). Po 2008 roku nastąpiła kilkuletnia stabilizacja, a nawet wzrost spożycia jabłek, co było przede wszystkim wynikiem intensywnie prowadzonych w naszym kraju kampanii promujących spożycie jabłek. Jak już wcześniej wspomniano w ostatnich kilkunastu latach wzrosła wyraźnie konsumpcja owoców południowych z poziomu 8,6 do $15 \mathrm{~kg} / \mathrm{os} / \mathrm{rok}$, tj. o 73,6\%. Na skutek tych zmian a także wzrostu spożycia innych, nowych lub wcześniej rzadko konsumowanych gatunków owoców, udział jabłek w strukturze spożycia owoców zmalał o ponad 15 pkt. proc.

\section{Eksport jabłek}

Zmniejszenie konsumpcji jabłek w ostatnich kilkunastu latach na rynku wewnętrznym wywołało potrzebę zagospodarowania ich wzrastającej produkcji poprzez eksport (Nosecka, 2014).

W latach 2005-2016 corocznie wywożono za granicę średnio 753,6 tys. ton jabłek (tab. 2). Udział eksportu w zagospodarowaniu krajowej produkcji jabłek wyniósł w badanym okresie średnio $29,8 \%$, a porównując skrajne analizowane lata wzrósł o blisko 10 pkt. proc. z 20,5\% do 30,3\%. Wolumen eksportu jabłek systematycznie zwiększał się z poziomu 426,3 tys. ton w pierwszym roku analizy do 1092,1 tys. ton w 2016 roku, co oznaczało wzrost o 156,2\%. Co roku wielkość eksportu wzrastała średnio o 58,3 tys. ton. W jeszcze szybszym tempie wzrastały wpływy ze sprzedaży zagranicznej jabłek. Średnio co roku wartość ich eksportu wynosiła $235 \mathrm{mln}$ euro, a na przestrzeni badanych lat zwiększyła się ponad 3 krotnie, z 91,3 do 316,8 mln euro. Średnio z roku na rok był to wzrost rzędu 27,2 mln euro.

W tym czasie zwiększył się także udział jabłek w eksporcie wszystkich owoców. W ujęciu ilościowym wzrósł z $67,4 \%$ do $79,9 \%$, a w ujęciu wartościowym z 40,3\% do 53,5\%. Średnio w latach 2005-2016 jabłka stanowiły 74,3\% wszystkich wywożonych zagranicę owoców, a udział wpływów z ich sprzedaży stanowił przeciętnie 51,2\% wartości eksportu owoców.

Najwięcej jabłek, 1230,4 tys. ton, za rekordową kwotę 446,6 mln euro, sprzedano zagranicę w 2013 roku. W kolejnym roku odnotowano jednak wyraźny spadek, który był konsekwencją rosyjskiego embarga, wprowadzonego w sierpniu 2014 roku. W kolejnych latach stało się ono główną przyczyną nadprodukcji jabłek w naszym kraju i spowodowało istotne zmiany w strukturze geograficznej ich eksportu. 
Tabela 2. Wielkość i wartość polskiego eksportu owoców ogółem oraz jabłek w latach 2005-2016

Table 2. The volume and value of Polish total fruit and apples exports in 2005-2016

\begin{tabular}{|c|c|c|c|c|c|c|c|c|c|c|c|c|c|}
\hline $\begin{array}{l}\text { Wyszcze- } \\
\text { gólnienie }\end{array}$ & 2005 & 2006 & 2007 & 2008 & 2009 & 2010 & 2011 & 2012 & 2013 & 2014 & 2015 & 2016 & $\begin{array}{c}\text { Dynamika } \\
\text { Zmian } \\
2016 / 2005 \\
2005=100\end{array}$ \\
\hline \multicolumn{14}{|c|}{ Wielkość eksportu (tys.ton) } \\
\hline $\begin{array}{l}\text { Owoce } \\
\text { ogółem }\end{array}$ & 633 & 583 & 646 & 654 & 993 & 913 & 776 & 1264 & 1515 & 1370 & 1176 & 1366 & 215,9 \\
\hline Jabłka & 426 & 398 & 450 & 410 & 777 & 725 & 534 & 958 & 1230 & 1096 & 946 & 1092 & 256,2 \\
\hline \multicolumn{14}{|c|}{ Udział jabłek w wielkości eksportu owoców ogółem (\%) } \\
\hline & 67,4 & 68,3 & 69,6 & 62,8 & 78,2 & 79,4 & 68,7 & 75,8 & 81,2 & 80,0 & 80,5 & 79,9 & \\
\hline \multicolumn{14}{|c|}{ Wartość eksportu (mln euro) } \\
\hline $\begin{array}{l}\text { Owoce } \\
\text { ogółem }\end{array}$ & 226,8 & 213,2 & 293,1 & 331,5 & 365,6 & 365,1 & 396,4 & 621,9 & 727,9 & 612,8 & 567,4 & 592,3 & 261,2 \\
\hline Jabłka & 91,3 & 97,1 & 132,2 & 138,2 & 203,3 & 203,7 & 201,4 & 338,5 & 446,6 & 351,6 & 299,5 & 316,8 & 347,0 \\
\hline \multicolumn{14}{|c|}{ Udział jabłek w wartości eksportu owoców ogółem (\%) } \\
\hline & 40,3 & 45,5 & 45,1 & 41,7 & 55,6 & 55,8 & 50,8 & 54,4 & 61,4 & 57,4 & 52,8 & 53,5 & \\
\hline
\end{tabular}

Źródło: obliczenia własne na podstawie (Rynek owoców..., 2006-2017).

W latach 2005-2016 największe ilości jabłek kierowano do krajów Wspólnoty Niepodległych Państw, średnio corocznie 521,5 tys. ton, co stanowiło 66,2\% polskiego eksportu tych owoców (tab.3). Kolejnymi pod względem wolumenu sprzedaży były państwa UE-13, do których eksportowano średnio 152,4 tys. ton jabłek oraz państwa UE-15 z wynikiem 85,8 tys. ton. Udziały tych dwóch grup krajów wyniosły odpowiednio $19,4 \%$ i $10,4 \%$. Odsetek eksportu do pozostałych państw kształtował się na średnim poziomie 3,5\%. Biorąc pod uwagę znaczenie poszczególnych krajów, zdecydowanie największymi importerami naszych jabłek były Rosja i Białoruś oraz Ukraina, do których na przestrzeni badanych lat sprzedano odpowiednio 27,7\%, 20,8\% i 13,1\% owoców. Wśród krajów Nowej Wspólnoty najwięcej, bo 6,4\% kierowano na Litwę, natomiast spośród państw UE-15 największym odbiorca naszych jabłek były Niemcy z 4,9\% udziałem w eksporcie. Najmniejsze znaczenie w strukturze geograficznej eksportu miały kraje pozostałe, których średni udział wyniósł 3,5\%. Ich znaczenie na przestrzeni lat jednak wzrastało, a ceny uzyskiwane ze sprzedaży jabłek w tych państwach osiagały najwyższe wartości, wynoszące średnio 0,44 euro $/ \mathrm{kg}$. Spośród tych krajów, polskim eksporterom najwięcej płacono w Indiach, Norwegii oraz Zjednoczonych Emiratach Arabskich, odpowiednio $0,59,0,58$ i 0,56 euro $/ \mathrm{kg}$. Jeżeli chodzi o inne grupy krajów na drugim miejscu uplasowały się kraje UE-15, z wynikiem 0,40 euro/kg, a za nimi kraje UE-13, ze średnimi cenami 0,36 euro $/ \mathrm{kg}$. Zdecydowanie najniższe ceny uzyskiwano w krajach WNP, a kształtowały się one na średnim poziomie 0,29 euro/kg. Najmniej za jabłka pochodzące z Polski płacono w Kazachstanie, Mołdawii i na Ukrainie, odpowiednio 0,21, 0,22 i 0,25 euro $/ \mathrm{kg}$. Średnia cena jabłek uzyskiwana w eksporcie w latach 2005-2016 wyniosła $0,32 \mathrm{euro} / \mathrm{kg}$.

Na przestrzeni badanych lat w strukturze geograficznej eksportu zaszły duże zmiany. W celu zobrazowania tych zmian badany okres podzielono, na 4 podokresy, przy czym w ostatnim $\mathrm{z}$ nich, tj. latach 2014/2015, ze względu na największe zmiany w tym podokresie przedstawiono także wartości dla poszczególnych lat. Uwzględniając dwa 
skrajne podokresy zwiększył się eksport do wszystkich grup państw, przy czym w strukturze wzrosło znaczenie krajów UE-15, WNP oraz krajów pozostałych, a jedyną grupa, której udział zmniejszył się były państwa Nowej Wspólnoty. Odsetek jabłek wysyłanych do krajów UE-12 spadł z 43,8\% do $25,1 \%$.

Tabela 3. Struktura geograficzna polskiego eksportu jabłek w latach 2005-2016

Table 3. Geographical structure of Polish apple exports in 2005-2016

\begin{tabular}{|c|c|c|c|c|c|c|c|c|c|c|c|c|c|c|c|}
\hline \multirow{2}{*}{ Kraje } & \multicolumn{2}{|c|}{$\begin{array}{l}2005 / 2006- \\
2007 / 2008\end{array}$} & \multicolumn{2}{|c|}{$\begin{array}{l}\text { 2008/2009- } \\
2010 / 2011\end{array}$} & \multicolumn{2}{|c|}{$\begin{array}{l}\text { 2011/2012- } \\
2013-2014\end{array}$} & \multicolumn{2}{|c|}{$2014 / 2015$} & \multicolumn{2}{|c|}{$2015 / 2016$} & \multicolumn{2}{|c|}{$2016 / 2017$} & \multicolumn{2}{|c|}{$\begin{array}{l}\text { 2014/2015- } \\
2016 / 2017\end{array}$} & \multirow{2}{*}{$\begin{array}{c}\text { Dynamika } \\
\text { zmian } \\
2016 / 2017 \\
/ 2005 / 2006 \\
2005 / 2006= \\
100\end{array}$} \\
\hline & $\begin{array}{l}\text { tys. } \\
\text { ton }\end{array}$ & $\%$ & $\begin{array}{l}\text { tys. } \\
\text { ton }\end{array}$ & $\%$ & $\begin{array}{l}\text { tys. } \\
\text { ton }\end{array}$ & $\%$ & $\begin{array}{l}\text { tys. } \\
\text { ton }\end{array}$ & $\%$ & $\begin{array}{l}\text { tys. } \\
\text { ton }\end{array}$ & $\%$ & $\begin{array}{l}\text { tys. } \\
\text { ton }\end{array}$ & $\%$ & $\begin{array}{l}\text { tys. } \\
\text { ton }\end{array}$ & $\%$ & \\
\hline UE-15 & 23,0 & 6,3 & 42,3 & 6,1 & 122,3 & 11,5 & 188,2 & 18,8 & 136,1 & 13,8 & 142,1 & 12,9 & 155,5 & 15,1 & 675,9 \\
\hline Niemcy & 10,1 & 2,8 & 16,7 & 2,4 & 51,1 & 4,8 & 115,8 & 11,5 & 57,7 & 5,9 & 53,5 & 4,9 & 75,7 & 7,4 & 749,2 \\
\hline Finlandia & 4,6 & 1,3 & 6,3 & 0,9 & 4,6 & 0,4 & 9,3 & 0,9 & 10,1 & 1,0 & 10,9 & 1,0 & 10,1 & 1,0 & 221,2 \\
\hline Szwecja & 3,0 & 0,8 & 6,4 & 0,9 & 6,4 & 0,6 & 8,6 & 0,9 & 10,1 & 1,0 & 12,7 & 1,2 & 10,5 & 1,0 & 345,1 \\
\hline Francja & 0,0 & 0,0 & 0,4 & 0,1 & 14,1 & 1,3 & 9,7 & 1,0 & 7,4 & 0,8 & 4,1 & 0,4 & 7,1 & 0,7 & - \\
\hline Holandia & 0,0 & 0,0 & 0,0 & 0,0 & 9,6 & 0,9 & 10,4 & 1,0 & 10,5 & 1,1 & 17,1 & 1,6 & 12,7 & 1,2 & - \\
\hline Wlk. Brytania & 0,0 & 0,0 & 0,7 & 0,1 & 8,5 & 0,8 & 6,9 & 0,7 & 6,4 & 0,7 & 10,5 & 1,0 & 7,9 & 0,8 & - \\
\hline UE-13 & 158,7 & 43,8 & 106,4 & 15,3 & 85,9 & 8,1 & 317,5 & 31,7 & 243,6 & 24,8 & 214,4 & 19,5 & 258,5 & 25,1 & 162,9 \\
\hline Litwa & 95,7 & 26,4 & 43,5 & 6,3 & 14,2 & 1,3 & 71,8 & 7,2 & 44,8 & 4,6 & 32,1 & 2,9 & 49,6 & 4,8 & 51,8 \\
\hline Lotwa & 12,7 & 3,5 & 10,0 & 1,4 & 10,0 & 0,9 & 65,5 & 6,5 & 45,8 & 4,7 & 18,7 & 1,7 & 43,3 & 4,2 & 342,1 \\
\hline Estonia & 6,1 & 1,7 & 7,6 & 1,1 & 5,6 & 0,5 & 8,6 & 0,9 & 9,7 & 1,0 & 11,1 & 1,0 & 9,8 & 1,0 & 161,5 \\
\hline Czechy & 21,6 & 6,0 & 15,1 & 2,2 & 14,5 & 1,4 & 59,7 & 6,0 & 38,6 & 3,9 & 37,4 & 3,4 & 45,2 & 4,4 & 209,1 \\
\hline Słowacja & 9,4 & 2,6 & 9,5 & 1,4 & 7,6 & 0,7 & 8,4 & 0,8 & 10,3 & 1,0 & 15,0 & 1,4 & 11,2 & 1,1 & 119,9 \\
\hline Rumunia & 11,5 & 3,2 & 18,9 & 2,7 & 27,4 & 2,6 & 50,7 & 5,1 & 63,7 & 6,5 & 64,4 & 5,8 & 59,6 & 5,8 & 518,3 \\
\hline WNP & 178,5 & 49,2 & 540,5 & 77,9 & 843,9 & 79,3 & 436,6 & 43,5 & 506,7 & 51,6 & 626,4 & 56,8 & 523,2 & 50,8 & 293,2 \\
\hline Rosja & 18,0 & 5,0 & 282,5 & 40,7 & 566,4 & 53,3 & 18,8 & 1,9 & 0,0 & 0,0 & 0,0 & 0,0 & 6,3 & 0,6 & 34,9 \\
\hline Białoruś & 43,4 & 12,0 & 39,8 & 5,7 & 165,9 & 15,6 & 290,0 & 28,9 & 422,8 & 43,0 & 504,2 & 45,8 & 405,7 & 39,4 & 934,0 \\
\hline Mołdawia & 7,1 & 2,0 & 0,0 & 0,0 & 0,0 & 0,0 & 2,4 & 0,2 & 0,0 & 0,0 & 0,0 & 0,0 & 0,8 & 0,1 & 11,2 \\
\hline Ukraina & 108,6 & 30,0 & 195,3 & 28,1 & 66,8 & 6,3 & 62,8 & 6,3 & 24,6 & 2,5 & 41,6 & 3,8 & 43,0 & 4,2 & 39,6 \\
\hline Kazachstan & 0,0 & 0,0 & 20,1 & 2,9 & 44,0 & 4,1 & 61,2 & 6,1 & 54,9 & 5,6 & 78,3 & 7,1 & 64,8 & 6,3 & - \\
\hline Pozostałe & 2,4 & 0,7 & 4,6 & 0,7 & 11,6 & 1,1 & 60,6 & 6,0 & 96,5 & 9,8 & 119,1 & 10,8 & 92,1 & 8,9 & 3836,1 \\
\hline Norwegia & 2,0 & 0,6 & 2,1 & 0,3 & 3,4 & 0,3 & 4,8 & 0,5 & 7,1 & 0,7 & 6,5 & 0,6 & 6,1 & 0,6 & 306,7 \\
\hline Serbia & 0,0 & 0,0 & 0,0 & 0,0 & 0,1 & 0,0 & 20,2 & 2,0 & 37,5 & 3,8 & 45,9 & 4,2 & 34,5 & 3,4 & - \\
\hline Egipt & 0,0 & 0,0 & 0,0 & 0,0 & 0,5 & 0,1 & 10,3 & 1,0 & 25,6 & 2,6 & 22,2 & 2,0 & 19,4 & 1,9 & - \\
\hline $\begin{array}{l}\text { Bośnia i } \\
\text { Hercegowina }\end{array}$ & 0,0 & 0,0 & 0,0 & 0,0 & 0,5 & 0,0 & 12,8 & 1,3 & 8,0 & 0,8 & 14,7 & 1,3 & 11,8 & 1,1 & - \\
\hline Gruzja & 0,0 & 0,0 & 0,0 & 0,0 & 0,2 & 0,0 & 1,0 & 0,1 & 0,0 & 0,0 & 0,0 & 0,0 & 0,3 & 0,0 & - \\
\hline Mongolia & 0,0 & 0,0 & 0,0 & 0,0 & 0,0 & 0,0 & 1,4 & 0,1 & 2,4 & 0,2 & 4,1 & 0,4 & 2,6 & 0,3 & - \\
\hline $\begin{array}{l}\text { Zjednoczone } \\
\text { Emiraty } \\
\text { Arabskie }\end{array}$ & 0,0 & 0,0 & 0,0 & 0,0 & 0,0 & 0,0 & 1,9 & 0,2 & 1,1 & 0,1 & 2,7 & 0,2 & 1,9 & 0,2 & - \\
\hline Indie & 0,0 & 0,0 & 0,0 & 0,0 & 0,0 & 0,0 & 0,4 & 0,0 & 1,7 & 0,2 & 5,0 & 0,5 & 2,4 & 0,2 & - \\
\hline Jordania & 0,0 & 0,0 & 0,0 & 0,0 & 0,0 & 0,0 & 0,5 & 0,0 & 2,2 & 0,2 & 6,4 & 0,6 & 3,0 & 0,3 & - \\
\hline
\end{tabular}

Źródło: obliczenia własne na podstawie (Rynek owoców..., 2006-2017). 
Analizując zmiany w strukturze geograficznej eksportu w latach 2005-2016, należy jednak zwrócić uwagę na dwa podokresy: do roku 2013/2014 i lata 2014/2015-2016/2017. Do roku 2013 dynamicznie wzrastała sprzedaż do WNP, w tym głównie do Rosji. W pierwszym podokresie eksportowano tam corocznie średnio 18 tys. ton jabłek, natomiast w latach 2008/2009-2013/2014 sprzedaż osiagnęła poziom 566,4 tys. ton. Na skutek tych zmian udział Rosji w strukturze eksportu wzrósł z 5\% do ponad $50 \%$. Należy dodać, iż w 2013 roku do Rosji sprzedano ok. 22\% polskiej produkcji jabłek. W tym czasie wzrastał także eksport na Białoruś oraz Ukrainę, przy czym w przypadku Ukrainy wzrost dotyczył tylko drugiego podokresu. W latach 2011/2012-2013/2014 odnotowano bowiem spadek sprzedaży. Poza krajami wschodnimi zwiększano eksport także do Niemiec. Wzrost ze średniego poziomu 10,1 tys. ton w latach 2005/2006-2007/2008 do 51,1 tys. ton w trzecim podokresie spowodował zwiększenie udziału w strukturze geograficznej naszego zachodniego sąsiada z 2,8\% do 4,8\%. W latach 2011/2012-2013/2014 wzrosła też sprzedaż do innych krajów Starej Wspólnoty, w tym głównie Francji, Holandii oraz Wielkiej Brytanii. Spadło natomiast znaczenie eksportu do krajów UE-13. Największe zmniejszenie sprzedaży dotyczyło takich państw jak Litwa, Czechy oraz Słowacja. Przełomowym momentem dla polskiego eksportu jabłek był sierpień 2014 roku. Wprowadzony przez Rosję zakaz przywozu polskich świeżych owoców i warzyw wpłynął znacząco na zmiany w strukturze geograficznej eksportu jabłek. Polskim eksporterom udało się częściowo ominąć rosyjskie embargo poprzez sprzedaż jabłek za pośrednictwem Białorusi. Efektem tego było ponad dwukrotne zwiększenie eksportu do tego kraju w ostatnim podokresie w stosunku do lat 2011/2012-2013/2014. Białoruś stała się tym samym największym importerem polskich jabłek, zwiększając swój udział w strukturze w sezonie 2016/2017 do $45,8 \%$, a całym trzyletnim okresie po 2014 roku do $39,4 \%$, co oznaczało wzrost o blisko $25 \%$. Sprzedaż do tego kraju częściowo tylko zrekompensowała zamknięcie rosyjskiego rynku, jednak polskim eksporterom udało się także zwiększyć sprzedaż na rynek unijny, w tym głównie do krajów UE-13. Największymi odbiorcami były tutaj Łotwa, Litwa oraz Czechy. Ponadto eksport zaczęto też kierować do innych państw Nowej Wspólnoty, takich jak Cypr, Bułgaria czy Rumunia. Mniejsze znaczenie w zagospodarowaniu jabłek wcześniej przeznaczanych na rynek rosyjski miały kraje UE-15. Podobnie jak przed rokiem 2014 najważniejszym importerem były Niemcy, gdzie w ostatnim podokresie skierowano o ok. 50\% więcej jabłek niż w latach 2011/2012-2013/2014. Zaistniała sytuacja wymusiła jednak poszukiwanie odbiorców nie tylko na rynku wewnętrznym UE, ale też na całym świecie (Ambroziak 20017). Po wprowadzeniu embarga przez Rosję wzrosło zatem także znaczenie pozostałych państw. Wielkość eksportu jabłek do tych krajów po roku 2014 sukcesywnie wzrastała, ze średniego poziomu 1,1 tys. ton w latach 2011/2012-2013/2014 do 92,1 tys. ton w ostatnim podokresie, a w sezonie 2016/2017 osiagnęła wielkość 119,1 tys. ton, co oznaczało wzrost ponad dziesięciokrotny. Z tej liczby, największe ilości, bo ponad $70 \%$ kierowano w tym okresie do Serbii, Egiptu oraz Bośni i Hercegowiny. Po roku 2014 polscy eksporterzy jabłek zdobywali także nowe rynki zbytu, takie jak Mongolia, Zjednoczone Emiraty Arabskie czy Jordania. W konsekwencji tego, w sezonie 2016/2017 polskie jabłka eksportowano do 75 krajów (Polańska 2017). Pomimo rozszerzenia eksportu do nowych krajów, zagraniczna sprzedaż jabłek w ostatnim podokresie zmalała. Główną barierą dla dalszego wzrostu eksportu jest ich jakość i struktura produkcji. Jakość i odmiany produkowane na rynek rosyjski często nie odpowiadają wymaganiom stawianym przez inne państwa. W państwach pozaeuropejskich przez konsumentów preferowane sa bowiem odmiany jednokolorowe, które jak wcześniej wspomniano stanowią niewielki 
procent polskiej produkcji. W związku z wyżej opisanymi zmianami i brakiem możliwości szybkiego reagowania polskich sadowników na zaistniała sytuację, ze względu na inwestycyjny charakter produkcji, polski rynek jabłek zmaga się z wysoką nadpodażą. Niemożliwe jest bowiem zagospodarowanie wszystkich pozostałych jabłek na rynku wewnętrznym ze względu na wspomniane wcześniej zmieniające się preferencje konsumentów w kierunku owoców południowych. Część jabłek kierowana jest do przetwórstwa, jednak i tutaj pojawia się problem związany z oferowanymi odmianami, gdyż jabłka deserowe często nie spełniają parametrów dla przetwórstwa. To wszystko wpływa negatywnie na sytuację w branży sadowniczej i czyni główny kierunek produkcji owoców coraz mniej opłacalnym.

\section{Podsumowanie i wnioski}

Przeprowadzona analiza pozwoliła na sformułowanie następujących wniosków: 1. W latach 2005-2016 uprawy jabłoni stanowiły średnio 43,7\% powierzchni upraw sadowniczych w Polsce a zbiory jabłek $72,7 \%$ zbiorów wszystkich owoców. Tempo wzrostu, zarówno powierzchni jak i wielkości produkcji jabłek było wyższe niż w przypadku wszystkich owoców, co wpłynęło na zwiększenie ich znaczenia w produkcji sadowniczej. Było to głównie rezultatem zmian w technologii produkcji, modernizacji gospodarstw i wynikającego $\mathrm{z}$ tego wzrostu plonów, a także organizowania się producentów jabłek oraz korzystania ze środków unijnych na rozwój gospodarstw.

2. W analizowanym okresie nastąiły istotne zmiany w strukturze odmianowej jabłek. Swoja pozycję umacniały odmiany przeznaczane na eksport, w tym głównie Idared, Gala, Jonagold czy Ligol. Na znaczeniu najbardziej traciły natomiast odmiany Lobo i Cortland, znajdujące zbyt głównie na rynku krajowym.

3. Spadek udziału odmian kierowanych na rynek detaliczny, w dużej mierze był wynikiem zmniejszenia spożycia jabłek $\mathrm{w}$ naszym kraju, które na przestrzeni analizowanych lat spadło o prawie $35 \%$. Główną tego przyczyną było zwiększenie spożycia owoców południowych oraz zmiana modelu żywienia Polaków i zwrot w kierunku produktów przetworzonych.

4. Zmniejszenie konsumpcji jabłek na rynku wewnętrznym wywołało potrzebę zagospodarowania ich wzrastającej produkcji poprzez eksport. Pojawiające się możliwości eksportu po roku 2005 stały się dodatkowo siłą napędową rozwoju polskiej produkcji jabłek. Na przestrzeni badanych lat udział eksportu w zagospodarowywaniu polskiej produkcji jabłek wzrósł z ok.20-30\%, a wpływy z ich sprzedaży zagranicznej zwiększyły się ponad trzykrotnie.

5. Duże zmiany odnotowano także w strukturze geograficznej eksportu jabłek. Na szczególne podkreślenie zasługuje wzrost znaczenia sprzedaży zagranicznej do krajów UE, ale przede wszystkim do Wspólnoty Niepodległych Państw, w tym głównie do Rosji. Krytycznym momentem na rynku jabłek w analizowanym okresie był rok 2014 i wprowadzony zakaz importu polskich owoców i warzyw do Rosji, naszego głównego importera jabłek. Wprowadzone embargo i dynamicznie wzrastająca produkcja doprowadziła do powstania nadpodaży na polskim rynku jabłek. Sprzedaż do Rosji została zastąpiona w większości eksportem do innych krajów WNP, w tym głównie na Białoruś a także do państw Unii Europejskiej. W strukturze geograficznej eksportu dużego 
znaczenia nabierały także kraje trzecie, a wśród nich głównie Egipt, Mongolia, Zjednoczone Emiraty Arabskie czy Jordania.

6. Pomimo rozszerzenia eksportu na nowe rynki zbytu oraz prowadzonych działań interwencyjnych, polegających min. na wycofywaniu części zbiorów z rynku, straty spowodowane rosyjskim embargiem wpłynęły na spadek opłacalności jabłek w ostatnich latach. W celu przywrócenia równowagi, konieczne będą w najbliższej przyszłości przede wszystkim zmiany w strukturze odmianowej jabłek i dostosowanie oferty dla potrzeb nowych rynków zbytu. Ważnymi punktami będą także poprawa logistyki, lepsza organizacja rynku pierwotnego, formowanie dużych, jednolitych partii owoców, a także intensywne działania promocyjne polskich jabłek w kraju i zagranica.

\section{Literatura}

Ambroziak, A.A. (2017). Wpływ embarga Federacji Rosyjskiej na eksport jabłek z Polski w latach 2004-2015 (Impact of the Russian Federation embargo on the export of apples from Poland in 2004-2015). Roczniki Rolnictwa i Rozwoju Obszarów Wiejskich, 104(1), 22-38

Bobrowska, A. (2013). Zmiany na rynku jabłek w Polsce z uwzględnieniem jabłek regionalnych (Changes on the apples market in Poland, including regional apples). Roczniki Rolnictwa i Rozwoju Obszarów Wiejskich, $100(1), 152-167$

Bugała, A. (2014). Światowy rynek jabłek i zagęszczonego soku jabłkowego (The world market of apples and concentrated apple juice). Zeszyty Naukowe SGGW Problemy Rolnictwa Światowego, 14(2), 21-30

Jąder, K. (2014). Zmiany w konsumpcji owoców i ich przetworów w Polsce w latach 1998-2012 (Changes in the consumption of fruit and their processed products in Poland in the years 1998-2012). Roczniki Naukowe Ekonomii Rolnictwa i Rozwoju Obszarów Wiejskich, 101(3), 98-106

Kierczyńska, S. (2015). Produkcja, eksport i ceny zagęszczonego soku jabłkowego a ceny skupu jabłek do przetwórstwa w Polsce (Production, export and prices of concentrated apple juice and apple purchase prices for processing in Poland). Roczniki Naukowe Ekonomii Rolnictwa i Rozwoju Obszarów Wiejskich, 101(3), 74-81.

Nosecka, B., Bugała, A., Paszko. D., Zaremba, Ł. (2012). Sytuacja na światowym rynku wybranych produktów ogrodniczych i jej wpływ na polski rynek ogrodniczy (The situation on the global market for selected horticultural products and its impact on the Polish horticultural marke)t. IERiGŻ-PIB, Warszawa.

Nosecka, B. (2014). Zewnętrzne uwarunkowania wzrostu eksportu owoców, warzyw i ich przetworów z Polski (External conditions for the growth of exports of fruit, vegetables and their products from Poland). Roczniki Naukowe Ekonomii rolnictwa i rozwoju Obszarów Wiejskich, 101(3), 133-144.

Polańska, M. (2017). Wyższy eksport jabłek (Higher apple exports). Hasło Ogrodnicze, 10, 68.

Raport of European Apple And Pear Crop Forecast, WAPA, sierpień 2017.

Rynek owoców $i$ warzyw. Stan i perspektywy (Fruit and vegetable market. Status and prospects), IERiGŻ-PIB, Warszawa, 2006-2017, nr 28-51.

Wyniki produkcji roślinnej $w$ latach 2005-2016 (Results of plant production in 2005-2016), GUS, 2006-2017, Warszawa.

http://ogrodnictwo.expert/prawo-ekonomia/prawo-ekonomia-ekonomia/dominujace-odmiany-jablek-w-polsce-ina-swiecie/ (dostęp: 30.09.2018).

https://www.e-sadownictwo.pl/artykuly/blog/5283-jeszcze-o-odmianach-jabloni-produkcja-ma-byc-oplacalnaposadz-odmiany-jednokolorowe (dostęp: 30.09.2018).

Do cytowania / For citation:

Jąder K. (2018). Produkcja, konsumpcja i eksport jabłek w Polsce w latach 2005 2016. Problemy Rolnictwa Światowego, 18(4), 209-221; DOI: 10.22630/PRS.2018.18.4.112

Jąder K. (2018). Production, Consumption and Export in Poland in the years 2005-2016 (in Polish). Problems of World Agriculture, 18(4), 209-221; DOI: 10.22630/PRS.2018.18.4.112 